\title{
REVIEW
}

\section{Fullerene nanoparticles and their anti-oxidative effects: a comparison to other radioprotective agents}

\author{
Jiřina Vávrová ${ }^{1}$, Martina Řezáčová $^{2}$, Jaroslav Pejchal $^{1}$ \\ ${ }^{1}$ Department of Radiobiology, University of Defence, Faculty of Military Health Sciences, Hradec Králové, \\ Czech Republic \\ ${ }^{2}$ Department of Medical Biochemistry, Faculty of Medicine in Hradec Králové, Charles University in Prague, \\ Czech Republic
}

Received $17^{\text {th }}$ August 2011.

Revised $31^{\text {st }}$ October 2011.

Published online $2^{\text {nd }}$ November 2011.

\begin{abstract}
Summary
Radiation therapy occupies an important position in the treatment of malignant diseases in spite of the existence of radiation side effects on normal tissues. Thus, substances are being developed which are designed to reduce both the acute and long term radiation effects on healthy tissues. Currently a sulphur-containing compound amifostine (WR2721, ethyol) is used in clinical practice as a radioprotectant. However, it itself has considerable side effects including hypotension (found in $62 \%$ of patients), hypocalcaemia, diarrhoea, nausea, and vomiting. Carbon nanospheres, known as fullerenes, and their water soluble derivatives (e.g. $\mathrm{C}_{60}(\mathrm{OH})_{24}$, dendrofullerene DF-1) exert anti-oxidative properties and reduce damage to the DNA in irradiated cells. Water soluble fullerenes are low-toxic substances and thus, are attractive in terms of their use as radioprotectants.
\end{abstract}

Key words: ionizing radiation; fullerenes; antioxidant; radioprotection; nanoparticles

\section{INTRODUCTION}

Radiotherapy is one of the major treatment modalities in the management of human cancer. However, it can lead to a number of side effects in the human body as a consequence of a series of events over different time periods varying from less than $10^{-12} \mathrm{~s}$ to many

$\triangle \quad$ Jiřina Vávrová, Department of Radiobiology, University of Defence, Faculty of Military Health Sciences, Třebešská 1575, 50001 Hradec Králové, Czech Republic vavrova@pmfhk.cz

용 +420973253214

目 $\quad+420495513018$

(C) Journal of Applied Biomedicine weeks. The energy transfer from a photon and/or a particle to atoms and molecules results in a direct change, i.e. a chemical conversion of a macromolecule, which could be of importance for the biological function. The critical event is damage to the DNA in the nucleus and formation of DNA double-strand breaks (DSB). This initial event can be caused by two mechanisms: either by direct damage to the DNA by the radiation energy or indirect damage mediated through radicals, peroxides and superoxides produced during the water radiolysis. In the case of radiation with low LET (Linear Energetic Transfer) including gamma radiation and X-rays, a prevalent proportion of the radiation damage results from the indirect mechanism. In this review the effect of classical radioprotectants is compared to the effect of water-soluble $\mathrm{C}_{60}$ fullerenes. 


\section{MECHANISM OF RADIOPROTECTION}

The radioprotection of living organisms by pharmacological substances particularly depends on their ability to reduce intracellular concentrations of free radicals and peroxides produced over the first milliseconds after irradiation. Substances, which could be used in the protection of healthy tissues from ionizing radiation effects in radiation therapy, should adhere to the following two basic conditions: 1) they must selectively protect normal tissues (without affecting tumour cells) and 2) they must exert minimum toxicity.

\section{Radioprotection due to hypoxia}

The degree of radiation damage to tissues directly correlates with their oxygenation. Substances able to reduce oxygenation can therefore have protective effects. A reduction of oxygen levels to $3-10 \%$ in the air inhaled during the course of irradiation can exert protective effects in mice and rats comparable to those achieved with traditional radioprotectants (Vacek et al. 1971). Radioprotectants taking advantage of hypoxia as the main mechanism of the effect include indolylalkylamines (serotonin and mexamine). The mechanism of their protective effect is explained by the post-vasoconstriction hypoxia (Zherebchenko and Suvorov 1963). However, given their side effects, such as a decrease in arterial blood pressure, a decrease in body temperature, and the teratogenic effect or degenerative changes in testicles (Kuna 1985), these substances did not find any use in clinical practice.

\section{Inactivation of oxidative radicals in water}

Strongly reactive oxygen radicals produced during irradiation by water radiolysis have harmful effects on the cell. Radical scavenging is the basic mechanism of many chemical substances and enzymes protecting biological targets against ionising radiation. It is essentially a competition for a radical between the protective substance and the biological molecule. In aqueous solutions, protective substances and enzymes react with free radicals and peroxides, produce stable non-toxic products and thus reduce the amounts of these species. Many of these radioprotectants are very good extinguishers of oxygen radicals. Compounds containing sulphur are well known radioprotectants exerting the highest protective effects, but they are also very toxic. In contrast, antioxidants of natural origin can be characterized by a relatively low toxicity, but also lower radioprotective properties.

\section{RADIOPROTECTIVE AGENTS}

\section{Sulphur containing compounds}

Radioprotectants containing sulphur are chemical analogues of cysteine (a thiol group containing amino acid). Similar to cysteine, these substances have their SH group separated by two to three carbon atoms from the basic amino group. To provide effective radioprotection, these substances must be present in the organism prior to irradiation. The optimum radioprotection is achieved in the case of an intravenous administration 15-30 $\mathrm{min}$ before irradiation. Sulphur containing compounds act through the mediation of three main mechanisms: as extinguishers of free radicals, as carriers of oxygen and last, but not least, they act as substances inducing hypoxic effects. The most well known radioprotectants of this group are cysteamine, cystamine AET and WR2721 (Bacq 1954, Dostál 1967, Kuna 1985).

The Walter Reed Military Institute in the USA has produced and tested 4000 compounds. In 1969, they synthesized a substance marked WR-2721 (Piper et al. 1969) (amifostine, ethyol) which is an organic thiophosphate prodrug (2-(3-aminopropylamino)ethylsulphanyl phosphonic acid) hydrolysed in vivo by alkaline phosphatase to the active cytoprotective thiol metabolite, WR-1065 (2-((aminopropyl)amino)ethanethiol). The selective protection of non-malignant tissues is believed to be related to higher alkaline phosphatase activity, higher $\mathrm{pH}$, and vascular permeation in normal tissues. The combination of hypovascularity, low $\mathrm{pH}$, and reduced enzyme levels results in a low accumulation of the active drug in tumour tissues (Kouvaris et al. 2007). Mean lethal doses were established for accurate determination of the radioprotective effects. These doses are typically related to the $30^{\text {th }}$ day after irradiation. LD50/30 is a lethal dose after which 50\% of animals survive up to the $30^{\text {th }}$ day after irradiation. The DRF (Dose Reducing Factor) is a ratio of the mean lethal dose in protected animals to that in non-protected animals. Table 1 presents DRF values of different radioprotectants used in mice. In the case of whole-body $\gamma$-ray irradiation, WR-2721 administered at a dose of $300 \mathrm{mg} / \mathrm{kg}$ is obviously the most effective radioprotectant (Kuna et al. 1983, Kuna 1985). No radioprotective effect of WR-2721 was found when it was administered at a dose of $160 \mathrm{mg} / \mathrm{kg}$ (intravenously or intramuscularly) to rats 15-20 min before their whole-body exposure to fission neutrons (Kuna et al. 2004). This is probably due to the fact that neutrons primarily damage biological molecules directly. WR-2721 also 
Vávrová et al.: Fullerene nanoparticles and their anti-oxidative effects

Table 1. Comparison of the radioprotective effect of DF-1 dendrofullerene with other known radioprotectants.

\begin{tabular}{|c|c|c|c|c|c|}
\hline Drug & Dose & Irradiation & Animals & $\mathrm{DRF}^{*}$ & Author \\
\hline WR-2721 & $\begin{array}{l}300 \mathrm{mg} / \mathrm{kg} \text { i.m. } \\
15-20 \mathrm{~min} \text { before irrad. }\end{array}$ & gamma & mice & 2.39 & Kuna 1985 \\
\hline WR-2721 & $\begin{array}{l}100 \mathrm{mg} / \mathrm{kg} \text { i.m. } \\
15-20 \mathrm{~min} \text { before irrad. }\end{array}$ & gamma & mice & 1.3 & Kuna 1985 \\
\hline Cystamine & $\begin{array}{l}175 \mathrm{mg} / \mathrm{kg} \text { i.m. } \\
5-15 \mathrm{~min} \text { before irrad. }\end{array}$ & gamma & mice & 1.83 & Kuna 1985 \\
\hline Superoxide-dismutase & $\begin{array}{l}\text { i.v. } 2 \mathrm{~h} \text { before irrad. }(200 \mathrm{mg} / \mathrm{kg}) \\
\text { and } 1 \mathrm{~h} \text { after irrad. }(35 \mathrm{mg} / \mathrm{kg})\end{array}$ & $\mathrm{X}$-rays & mice & 1.56 & Petkau 1978 \\
\hline Hypoxia $-8 \% \mathrm{O}_{2}$ & in the course of irrad. & gamma & mice & 1.5 & $\begin{array}{l}\text { Vacek et al. } \\
1971\end{array}$ \\
\hline $\begin{array}{l}\text { DF-1 dendrofullerene } \\
\text { nanoparticle }\end{array}$ & $\begin{array}{l}300 \mathrm{mg} / \mathrm{kg} \\
15 \mathrm{~min} \text { before irrad. }\end{array}$ & $\mathrm{X}$-rays & mice & 1.22 & Brown 2010 \\
\hline
\end{tabular}

* The DRF (the Dose Reducing Factor) is a ratio of the mean lethal dose (LD50/30) in protected animals to that in non-protected ones.

considerably reduces the toxicity of chemotherapeutic agents, particularly of cisplatin (Yuhas 1980).

The undesirable side effects of WR-2721 are related to the application of high doses. The LD50/48 value for mouse strain $\mathrm{H}$ after an intra peritoneal (i.p.) administration was $764-1054 \mathrm{mg} / \mathrm{kg}$. The best radioprotective effect was achieved by an i.p. application of $300 \mathrm{mg} / \mathrm{kg}$, when DRF was $2.11-2.39$. A decrease in the dose to $100 \mathrm{mg} / \mathrm{kg}$ caused a significant decrease in the protective effect (DRF = 1.3) (Kuna 1985). The side effects of WR-2721 include hypotension, hypocalcaemia, diarrhoea and nausea (France et al. 1986). Hwang et al. (2004) applied WR-2721 to patients during myeloablative conditioning therapy for allogenic bone marrow transplantation. WR-2721 was administered at a dose of $1000 \mathrm{mg} /$ day of conditioning and was well tolerated if attention was paid to the serum calcium level, blood pressure and antiemetics.

\section{Antioxidants of natural origin}

There are a few substances of natural origin that are able to protect cells from the negative effects of free radicals and reactive oxygen species. These substances can be divided into two groups: 1) low-molecular substances acting as scavengers of oxygen radicals and 2) enzymes detoxifying reactive oxygen radicals and peroxides.
The low-molecular compounds acting as oxygen radical scavengers include vitamins $\mathrm{A}$ and $\mathrm{E}$, which are lipophilic, and vitamin C, which is hydrophilic. Several studies have established the radioprotective values of vitamins $\mathrm{A}, \mathrm{C}$ and $\mathrm{E}$ and carotenoids in normal cells (Malick et al. 1978, Konopacka et al. 1998, Prasad et al. 2002). In these compounds, the DRF values range between 1.1 and 1.2. Lipophilic vitamins $\mathrm{A}$ and $\mathrm{E}$ administrated i.p. and hydrophilic vitamin $\mathrm{C}$ administered i.m. to mice for 14 days ( 3 days before immunoradiotherapy and 11 days after immunoradiotherapy) reduced the body weight loss and myelosupression associated with radioimmunotherapy (Blumenthal et al. 2000).

The group of enzymes with antioxidant properties includes superoxide-dismutase (SOD), catalase, glutathione peroxidase and glutathione reductase (Citrin et al. 2010) and these are described below.

\section{Superoxide-dismutase (SOD)}

Superoxide-dismutase is an enzyme important for the detoxification of reactive oxygen radicals catalyzing the superoxide radical conversion to hydrogen peroxide $\left(\mathrm{H}_{2} \mathrm{O}_{2}\right)$ and hydrogen. $\mathrm{H}_{2} \mathrm{O}_{2}$ is subsequently removed by a reaction with the participation of two enzymes (catalase and glutathione peroxidase). The administration of superoxide-dismutase $2 \mathrm{~h}$ prior to irradiation $(200 \mathrm{mg} / \mathrm{kg})$ and $1 \mathrm{~h}$ after irradiation $(35 \mathrm{mg} / \mathrm{kg}$ ) provides a relatively high radioprotective 
effect $-\mathrm{DRF}=1.58$ (Petkau 1978). In contrast to radioprotectants containing sulphur, these enzymes exert only a minimum toxicity.

In terms of radiation damage, not only DNA impairment is important, but also the damage to mitochondria mediated through the production of superoxide and other reactive oxygen species (ROS) derived from superoxide. An increased ROS production can be observed in the irradiated tissues 6 months after the exposure (Epperly et al. 2008). The damage to the mitochondria is manifested by induction of apoptosis. Manganese superoxide dismutase (MnSOD), which is an enzyme present in human cells, is actually the first line of defense against an increased superoxide production in the mitochondria (Belikova et al. 2009). Thus, antioxidant gene therapy studies have utilised manganese superoxide dismutase-plasmid liposomes (MnSOD-PL). Overexpression of the mitochondria localized MnSOD gene product have been shown to decrease the ionizing radiation-induced apoptosis of cells in vitro (Epperly et al. 2002). In the case of intravenous application of MnSOD-PL to mice before their exposure to $9.5 \mathrm{~Gy}$ (antioxidant gene therapy the mice received intravenously $100 \mu \mathrm{l}$ of liposomes containing $100 \mu \mathrm{g}$ of human MnSOD-transgene plasmid 24 hours prior to irradiation), increased animal survival was observed 30 days as well as 340 days after irradiation (Epperly et al. 2008).

\section{Fullerene - derivatives}

Compounds developed based on nanotechnology, such as for example, carbon nanospheres named fullerenes $\left(\mathrm{C}_{60}, \mathrm{C}_{70}, \mathrm{C}_{80}-\mathrm{C}_{200}\right)$ also represent an important group of antioxidants due to the possible absorption of many oxygen radicals in a single fullerene molecule (Bosi et al. 2003). The most abundant form of fullerenes is buckminsterfullerene $\mathrm{C}_{60}$ (Fig. 1) with 60 carbon atoms arranged in a spherical structure (Marković and Trajković 2008).

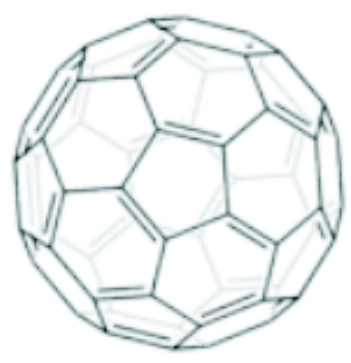

Fig. 1. Structure of fullerene $\mathbf{C}_{60}$.
$\mathrm{C}_{60}$ is soluble in aromatic solvents and carbon disulfide but essentially insoluble in water and alcohol (Jensen et al. 1996). For their use in biology, it is necessary to obtain fullerene derivatives, which are soluble in polar solvents. Chemical modification of the fullerene carbon cage by the attachment of various functional groups (e.g.- $\mathrm{OH}, \mathrm{NH}_{2},-\mathrm{COOH}$ ) enables the fullerene molecule to establish bonds with water via hydrophilic functional adducts (Marković and Trajković 2008). Johnston et al. (2010) reviewed analyses of the toxicity of fullerenes in detail. Manipulating fullerene water solubility has included the use of surface modifications, solvents, extended stirring, and mechanical processes. However, the ability of these processes to have an impact on fullerene toxicity requires further assessment, especially when considering the use of solvents, which particularly enhance the toxicity of fullerene derivates (Johnston et al. (2010).

\section{Inhibition of HIV replication}

These substances were also shown to possess considerable antiviral effects. In 1993, the water-soluble derivative of $\mathrm{C}_{60}$ [bis(monosuccinimide) derivative of bis(2-aminoethyl)diphenyl- $\mathrm{C}_{60}$ ] was found to be a substance inhibiting HIV-1 protease (Schinazi et al. 1993). A derivative of tris-hydroxymethyl methano-fullerene was later discovered to exert an even higher antiviral activity (Jensen et al. 1996). The antiviral activity seems to be characteristic for many non-toxic derivatives of the $\mathrm{C}_{60}$ fullerene (Friedmann et al. 1998, Cheng et al. 2010).

\section{Photodynamic therapy of tumours}

Mroz et al. (2007) showed that the $\mathrm{C}_{60}$ molecule mono-substituted with a single pyrollidinium group is a remarkably efficient photosensibilizer and can mediate the killing of a panel of mouse cancer after exposure to white light. Following intravenous injection of $\mathrm{C}_{60}$-PEG (polyethylene glycol - PEG conjugated with $\mathrm{C}_{60}$ ) to tumour-bearing mice, coupled with exposure of the tumour site to visible light, the volume increase of tumour mass was suppressed and $\mathrm{C}_{60}$-PEG conjugate exhibited a stronger suppressive effect than Photofrin (Tabata et al. 1997, Liu et al. 2007). These data demonstrate the potential use of these compounds as photo-sensibilizers for photodynamic therapy of tumours.

\section{Antioxidant activity}

Oxidative stress and associated oxidative damage are mediators of cellular injury in many pathological conditions, including autoimmunity, atherosclerosis, diabetes, and neurodegenerative disorders (Marković 
and Trajković 2008). In many studies, it has been shown that water-soluble fullerene derivates can act as antioxidant substances scavenging oxygen radicals (including ROS generated by ionising radiation) and protecting cells and/or tissues against ROS damage. The known antioxidant activity of water soluble $\mathrm{C}_{60}$ derivatives is summarized in Table 2 .

Table 2. Water soluble $\mathbf{C}_{60}$ derivates and their antioxidative effects.

\begin{tabular}{lll}
\hline Fullerene type & Biological effects & Author \\
\hline $\mathrm{C}_{60}(\mathrm{OH})_{24}$ & $\begin{array}{l}\text { radioprotection } \\
\text { protection from doxorubicin toxicity }\end{array}$ & $\begin{array}{l}\text { Trajković et al. 2007, Cai et al. 2010 } \\
\text { Injac et al. 2008 }\end{array}$ \\
$\mathrm{C}_{60}(\mathrm{OH})_{22}$ & $\begin{array}{l}\text { protection from } \mathrm{H}_{2} \mathrm{O}_{2} \text { induced } \\
\text { oxidative injury }\end{array}$ & Yin et al. 2008 \\
$\begin{array}{l}\text { Malonic acid } \mathrm{C}_{60} \text { derivates } \\
\text { carboxyfullerenes }\end{array}$ & neuroprotection & Dugan et al. 1996, 2001, \\
$\mathrm{C}_{60}$ dendrofullerene & radioprotection & Ali et al. 2008 \\
Polyvinylpyrrolidone wrapped $\mathrm{C}_{60}$ & reduces synovitis & Brown et al. 2010, Theriot et al. 2010 \\
\hline
\end{tabular}

For instance, polyhydroxylated fullerenes $\mathrm{C}_{60}(\mathrm{OH})_{\mathrm{x}}$, also referred to as fullerenols, were studied by Trajković et al. (2007) and Cai et al. (2010). Trajković et al. (2007) demonstrated the radioprotective effect of fullerenol $\left(\mathrm{C}_{60}(\mathrm{OH})_{24}\right)$ administered to rats intraperitoneally in a dose of $100 \mathrm{mg} / \mathrm{kg} 30 \mathrm{~min}$ prior to $8 \mathrm{~Gy}$ irradiation. The fullerenol protected the rats' haemopoietic and lymphoid tissues. Cai et al. (2010) studied the radioprotective effects of repeated fullerenol administrations (for a period of 14 days) at a dose of $40 \mathrm{mg} / \mathrm{kg}$ on the mouse immune system. It was found that 2-week $\mathrm{C}_{60}(\mathrm{OH})_{24}$ pretreatment effectively reduced whole body irradiation-induced mortality without apparent toxicity. $\mathrm{C}_{60}(\mathrm{OH})_{24}$ pretreatment also showed significant protective effects against ionizingradiation-induced decreases in immune and mitochondrial function and antioxidant defense in the liver and spleen. This suggests that the polyhydroxylated fullerene derivative $\mathrm{C}_{60}(\mathrm{OH})_{24}$ protects against ionizing-radiation-induced mortality, possibly by enhancing the immune function, decreasing oxidative damage and improving the mitochondrial function.

The antioxidant and protective properties of carboxy-fullerenes have been described by Dugan et al. (1996) and Ali et al. (2008). Both studies showed that carboxy-fullerenes are able to protect neurons against the oxidative stress associated with Parkinson's disease and ischaemic brain injury. Moreover, Ali et al. (2008) compared the structure of
6 carboxy-fullerenes and found the best antioxidative effect in the tris-adduct malonic acid derivate of fullerene $-\mathrm{C}_{60}\left(\mathrm{C}(\mathrm{COOH})_{2}\right)_{3}$. Ali et al. (2008) described carboxy-fullerenes as three-dimensional carbon carriers with the antioxidative properties depending not only on the number of bound carboxylic groups but also on their distribution on the fullerene ball.

The ability of fullerenes to modulate cytokine production and cellular damage was shown in bis-adduct malonic acid derivate and water-soluble $\mathrm{C}_{60}$ fullerene (polyvinylpyrrolidone wrapped $\mathrm{C}_{60}$ ). Bis-adduct malonic acid derivate inhibited the TNF-alpha initiated apoptosis in HeLa cells (Li et al. 2011). On the other hand, findings by Yudoh et al. (2009) indicate that polyvinylpyrrolidone wrapped $\mathrm{C}_{60}$ reduces pro-inflammatory cytokine production from synovial inflammation-related cells and mitigates the resultant synovitis in vitro. Intraarticular treatment with this compound significantly attenuates synovitis and joint destruction in the rat model of arthritis.

Another promising fullerene derivate is dendro (60) fullerene-1 (DF-1). The derivate is characterised by a single branched dendromer architecture containing 18 terminal carboxylic groups attached to the fullerene ball. DF-1 is readily soluble in water, is non-toxic and has radioprotective effects (Brown et al. 2010, Theriot et al. 2010). Theriot et al. (2010) has shown that DF-1 protects lymphocytes as well as cells in the intestinal crypts from radiation-induced cell 
death. In this study, human lymphocytes and rat intestinal crypt cells (IEC-6) were incubated with $100 \mu \mathrm{M}$ DF-1 one hour prior to irradiation, rinsed and immediately exposed to a single dose of $4 \mathrm{~Gy}$ in the fresh medium. The study shows that 1-hour incubation with DF-1 reduces the number of micronuclei (an indicator of DNA damage) in both types of cells compared to the irradiated non-protected groups. Brown et al. (2010) evaluated the DF-1 DNA protective effects via the expression of phosphorylated histone $\mathrm{H} 2 \mathrm{AX}(\gamma-\mathrm{H} 2 \mathrm{AX}) . \Gamma-\mathrm{H} 2 \mathrm{AX}$ serves as an indicator of DNA double strand brakes. In the DU145 cell culture, a 30-min pre-treatment with $100 \mu \mathrm{M}$ DF-1 resulted in a significant decrease in the number of $\gamma$ - H2AX foci 1 and $6 \mathrm{~h}$ after $4 \mathrm{~Gy}$ irradiation. Both studies demonstrate that there is a reduction in DNA damage after DF-1 incubation and that DF-1 acts not only against the oxidative stress but also against the DNA damage generated by ionizing radiation.

\section{CONCLUSION}

Polyamino- and polyhydroxy-fullerenes show that water-solubility increases with the number of groups introduced into the molecule. It is possible to state conclusively that water-soluble fullerene derivatives exert considerable protective effects against the oxidative stress as scavengers of free radicals in vitro as well as in vivo (Dugan et al. 2001, Ali et al. 2004, Bakry et al. 2007, Injac et al. 2008). The radioprotective effects were demonstrated in fullerenols, carboxy-fullerenes, polyvinylpyrrolidone wrapped fullerene, and DF-1. Table 1 summarizes a comparison of the DRFs after a single water-soluble dendrofullerene DF-1 application 30 min before irradiation $(\mathrm{DRF}=1.22)$ with the effects of other radioprotectants. Given the fact that these substances (fullerenol, DF-1) have no or only slight side effects, they offer a great potential to become radioprotectants with the possibility of repeated administration, which is necessary in standard fractionated radiotherapy.

\section{ACKNOWLEDGEMENTS}

The authors would like to thank the Ministry of Defence of Czech Republic (project MO0FVZ0000501 and project OVUOFVZ200806) for financial support.

\section{REFERENCES}

Ali SS, Hardt JI, Quick KL, Sook Kim-Han J, Erlanger BF, Huang TT, Epstein CJ, Dugan LL. A biologically effective fullerene $\left(\mathrm{C}_{60}\right)$ derivative with superoxide dismutase mimetic properties. Free Radic Biol Med. 37: 1191-1202, 2004.

Ali SS, Hardt JI, Dugan LL. SOD activity of carboxyfullerenes predicts their neuroprotective efficacy: a structure-activity study. Nanomedicine. 4: 283-294, 2008.

Bacq ZM. The amines and particularly cysteamine as protectors against roentgen rays. Acta Radiol. 41: 47-55, 1954.

Bakry R, Vallant RM, Najam-ul-Haq M, Rainer M, Szabo Z, Huck CW, Bonn GK. Medicinal applications of fullerenes. Int J Nanomedicine. 2: 639-649, 2007.

Belikova NA, Glumac A, Rafikov R, Jiang J, Greenberger JS, Kagan VE, Bayir $\mathrm{H}$. Radioprotection by short-term oxidative preconditioning: role of manganese superoxide dismutase. FEBS Lett. 583: 3437-3442, 2009.

Blumenthal RD, Lew W, Reising A, Soyne D, Osorio L, Ying Z, Goldenberg DM. Anti-oxidant vitamins reduce normal tissue toxicity induced by radio-immunotherapy. Int J Cancer. 86: 276-280, 2000.

Bosi S, Da Ros T, Spalluto G, Prato M. Fullerene derivatives: an attractive tool for biological applications. Eur J Med Chem. 38: 913-923, 2003.

Brown AP, Chung EJ, Urick ME, Shield WP $3^{\text {rd }}$, Sowers AL, Thetford A, Shankavaram UT, Mitchell JB, Citrin DE. Evaluation of the fullerene compound DF-1 as a radiation protector. Radiat Oncol. 5: 34, 2010.

Cai X, Hao J, Zhang X, Yu B, Ren J, Luo C, Li Q, Huang Q, Shi X, Li W, Liu J. The polyhydroxylated fullerene derivative $\mathrm{C}_{60}(\mathrm{OH})_{24}$ protects mice from ionizing-radiation-induced immune and mitochondrial dysfunction. Toxicol Appl Pharmacol. 243: 27-34, 2010.

Cheng Y, Li D, Ji B, Shi X, Gao H. Structure-based design of carbon nanotubes as HIV-1 protease inhibitors: atomistic and coarse-grained simulations. J Mol Graph Model. 29: 171-177, 2010.

Citrin D, Cotrim AP, Hyodo F, Baum BJ, Krishna MC, Mitchell JB. Radioprotectors and mitigators of radiation-induced normal tissue injury. Oncologist. 15: 360-371, 2010.

Dostál M. Protective effect of cystamine before radiation (in Czech). PhD. thesis, Purkyně Military Medical Research and Postgraduate Institute, Hradec Králové 1967. 
Dugan LL, Gabrielsen JK, Yu SP, Lin TS, Choi DW. Buckminsterfullerenol free radical scavengers reduce excitotoxic and apoptotic death of cultured cortical neurons. Neurobiol Dis. 3: 129-135, 1996.

Dugan LL, Lovett EG, Quick KL, Lotharius J, Lin TT, O’Malley KL. Fullerene-based antioxidants and neurodegenerative disorders. Parkinsonism Relat Disord. 7: 243-246, 2001.

Epperly MW, Sikora CA, DeFilippi SJ, Gretton JA, Zhan Q, Kufe DW, Greenberger JS. Manganese superoxide dismutase (SOD2) inhibits radiation-induced apoptosis by stabilization of the mitochondrial membrane. Radiat Res. 157: 568-577, 2002.

Epperly MW, Dixon T, Wang H, Schlesselman J, Franicola D, Greenberger JS. Modulation of radiation-induced life shortening by systemic intravenous MnSOD-plasmid liposome gene therapy. Radiat Res. 170: 437-443, 2008.

France HG, Jr., Jirtle RL, Mansbach CM. Intracolonic WR 2721 protection of the rat colon from acute radiation injury. Gastroenterology. 91: 644-650, 1986.

Friedman SH, Ganapathi PS, Rubin Y, Kenyon GL. Optimizing the binding of fullerene inhibitors of the HIV-1 protease through predicted increases in hydrophobic desolvation. J Med Chem. 41: 2424-2429, 1998.

Hwang WY, Koh LP, Ng HJ, Tan PH, Chuah CT, Fook SC, Chow H, Tan KW, Wong C, Tan CH, Goh YT. A randomized trial of amifostine as a cytoprotectant for patients receiving myeloablative therapy for allogeneic hematopoietic stem cell transplantation. Bone Marrow Transplant. 34: 51-56, 2004.

Injac R, Boskovic M, Perse M, Koprivec-Furlan E, Cerar A, Djordjevic A, Strukelj B. Acute doxorubicin nephrotoxicity in rats with malignant neoplasm can be successfully treated with fullerenol $\mathrm{C}_{60}(\mathrm{OH})_{24}$ via suppression of oxidative stress. Pharmacol Rep. 60: 742-749, 2008.

Jensen AW, Wilson SR, Schuster DI. Biological applications of fullerenes. Bioorg Med Chem. 4: 767-779, 1996.

Johnston HJ, Hutchison GR, Christensen FM, Aschberger K, Stone V. The biological mechanisms and physicochemical characteristics responsible for driving fullerene toxicity. Toxicol Sci. 114: 162-182, 2010.

Konopacka M, Widel M, Rzeszowska-Wolny J. Modifying effect of vitamins C, E and beta-carotene against gamma-ray-induced DNA damage in mouse cells. Mutat Res. 417: 85-94, 1998.
Kouvaris JR, Kouloulias VE, Vlahos LJ. Amifostine: the first selective-target and broad-spectrum radioprotector. Oncologist. 12: 738-747, 2007.

Kuna P. Chemical radioprotection (in Czech). Avicenum, Praha 1985.

Kuna P, Volenec K, Vodička I, Dostál M. Radioprotective and hemodynamic effects of WR-2721 and cystamine in rats: time course studies. Neoplasma. 30: 349-357, 1983.

Kuna P, Dostál M, Neruda O, Knajfl J, Petýrek P, Podzimek F, Severa J, Svoboda V, Šimša J, Špelda S, Vávrová J, Heřmanská J. Acute toxicity and radioprotective effects of amifostine (WR-2721) or cystamine in single whole body fission neutrons irradiated rats. J Applied Biomed. 2: 43-49, 2004.

Li W, Zhao L, Wei T, Zhao Y, Chen C. The inhibition of death receptor mediated apoptosis through lysosome stabilization following internalization of carboxyfullerene nanoparticles. Biomaterials. 32: 4030-4041, 2011.

Liu J, Ohta S, Sonoda A, Yamada M, Yamamoto M, Nitta N, Murata K, Tabata Y. Preparation of PEG-conjugated fullerene containing $\mathrm{Gd} 3+$ ions for photodynamic therapy. J Control Release. 117: 104-110, 2007.

Malick MA, Roy RM, Sternberg J. Effect of vitamin $\mathrm{E}$ on post irradiation death in mice. Experientia. 34: 1216-1217, 1978 .

Marković Z, Trajković V. Biomedical potential of the reactive oxygen species generation and quenching by fullerenes $\left(\mathrm{C}_{60}\right)$. Biomaterials. 29: 3561-3573, 2008.

Mroz P, Tegos GP, Gali H, Wharton T, Sarna T, Hamblin MR. Photodynamic therapy with fullerenes. Photochem Photobiol Sci. 6: 11391149, 2007.

Petkau A. Radiation protection by superoxide dismutase. Photochem Photobiol. 28: 765-774, 1978.

Piper JR, Stringfellow CR, Jr., Elliott RD, Johnston TP. Terminally substituted S-2-( $\omega$-Amino-alkylamino) ethyl dihydrogen phosphorothioates and related compounds as potential antiradiation agents. J Med Chem. 12: 236-243, 1969.

Prasad KN, Cole WC, Kumar B, Che Prasad K. Pros and cons of antioxidant use during radiation therapy. Cancer Treat Rev. 28: 79-91, 2002.

Schinazi RF, Sijbesma R, Srdanov G, Hill CL, Wudl F. Synthesis and virucidal activity of a water-soluble, configurationally stable, derivatized C60 fullerene. Antimicrob Agents Chemother. 37: 1707-1710, 1993.

Tabata Y, Murakami Y, Ikada Y. Photodynamic effect of polyethylene glycol-modified fullerene 
on tumor. Jpn J Cancer Res. 88: 1108-1116, 1997.

Trajković S, Dobrić S, Jaćević V, Dragojević-Simić V, Milovanović Z, Dordević A. Tissue-protective effects of fullerenol $\mathrm{C}_{60}(\mathrm{OH})_{24}$ and amifostine in irradiated rats. Colloids Surf B Biointerfaces. 58: 39-43, 2007.

Theriot CA, Casey RC, Moore VC, Mitchell L, Reynolds JO, Burgoyne M, Partha R, Huff JL, Conyers JL, Jeevarajan A, Wu H. Dendro $\left[\mathrm{C}_{60}\right]$ fullerene $\mathrm{DF}-1$ provides radioprotection to radiosensitive mammalian cells. Radiat Environ Biophys. 49: 437-445, 2010.

Vacek A, Rotkovská D, Raková A. The protective effect of hypoxia against repeated irradiation of mice. Int J Radiat Biol Relat Stud Phys Chem Med. 19: 323-328, 1971.
Yin JJ, Lao F, Fu PP, Wamer WG, Zhao Y, Wang PC, Qiu Y, Sun B, Xing G, Dong J, Liang XJ, Chen $\mathrm{C}$. The scavenging of reactive oxygen species and the potential for cell protection by functionalized fullerene materials. Biomaterials. 30: 611-621, 2008.

Yudoh K, Karasawa R, Masuko K, Kato T. Water-soluble fullerene (C60) inhibits the development of arthritis in the rat model of arthritis. Int J Nanomedicine. 4: 217-225, 2009.

Yuhas JM. A more general role for WR-2721 in cancer therapy. Br J Cancer. 41: 832-834, 1980.

Zherebchenko PG, Suvorov NN. The Relation between the radioprotective and vasoconstrictive action of indolyl alkalylamines (in Russian). Radiobiologiia. 3: 595-602, 1963. 